\title{
Increasing Students Engagement in Data Structure Course Using Gamification
}

\author{
Reem S. Al-Towirgi ${ }^{1,2}$, Lamya F. Daghestani ${ }^{1}$, Lamiaa F. Ibrahim ${ }^{1} 3^{*}$ \\ 1 Department of Computer Science, Faculty of Computing and Information Technology, King Abdulaziz \\ University Jeddah, Saudi Arabia. \\ 2 Department of Computer Science, Faculty of Computing and Information Technology, Taif University, Taif, \\ Saudi Arabia. \\ ${ }^{3}$ Computer Science Department, Institute of Statistical Studies and Research, Cairo University. \\ * Corresponding author. Tel.: +966557279106; email: lfibrahim@kau.edu.sa \\ Manuscript submitted January 10, 2018; accepted March 8, 2018. \\ doi: 10.17706/ijeeee.2018.8.4.193-211
}

\begin{abstract}
Gamification is the use of game elements in non-game context. It is used in many industries and recently in education to increase students engagement. In this paper a gamified data structure course was developed to teach students the main topics of data structure. The effectiveness of gamification on learning performance and students engagement will be evaluated. Results show that gamification has a positive impact on learning performance and it increases the student engagement.
\end{abstract}

Key words: Data structure, e-learning, engagement, gamification, gamified course.

\section{Introduction}

Games begin to pervade the real world and have been a large part of human life. The power of games comes from its ability to engage users and affect their emotions through its mechanics and dynamics. Game mechanics are elements like points, tokens and badges. Game dynamics are designed rules that describe how to collect elements and reach achievements [1], [2].Game mechanics and dynamics are used to trigger player emotion, this is called aesthetics of the game [1]. Gamification has emerged recently to increase user engagement by using these aesthetics in serious context [3].

In education, engagement is considered as a valuable indicator of the academic achievement of the student. One of the most successful methods used to raising students' engagement are games which can create engaging learning for students [4].

There are many types of games used to improve knowledge in different fields but rather than creating actual game, gamification grafts elements that makes video game fun and effective and applies them to any learning environment. Gamification was used in traditional learning. For example: developing a leaderboard containing the best students, giving a ribbon or a badge for the excellent student.

In our work we will increase the effectiveness of e-learning using gamification and create a gamified data structure course to increase students' engagement. This paper is organized as follow: Section two presents a background about e-learning and gamification. Section three lists the related works on using gamification in education. Section four presents the system design. Section five explains the system implementation. Section six describes the experimental study. Section seven discuss the results. Section eight present a conclusion and future work. 


\section{Background}

Among the years, learning process has improved from traditional system in the classrooms to electronic ones using information technology [5]. The use of information technology to deliver information for education and training leads to E-learning [6].

\subsection{E-Learning}

E-learning is defined as information and communication technologies used to support students to improve their learning [7]. Normarkin [8] defines e-learning as the ability of the system to electronically transfer, manage, support and supervise learning and learning materials. E-learning has many advantages [9]: it enables learning anywhere and anytime, it controls learner with more flexibility and it delivers courses with low cost.

\subsection{Learning Management System}

To facilitate the interaction between students and teachers in e-learning, Learning Management Systems (LMSs) were created. LMS is defined as a system that automates the different processes of educational course such as: administration, tracking and scoring [10]. It has features like content development, content access and users assessment.

Nowadays, most of the educational institutions use LMS to increase the effectiveness of their learning process [11]. The purpose of LMS is to assist teachers and students to communicate with each other, discuss course topics and exchange their ideas through the features implemented in these systems [12].

In the old LMS only simple features were found such as: file storage and sharing. More advanced features were introduced overtime such as: course management, materials adapting and reusing, assessment and surveys, calendars, assignments and forums [13].

Currently, The most popular LMSs are Moodle and Blackboard [14]. Moodle is a free online LMS providing an open source solution for e-learning which is secure and customizable with a large selection of available activities [15]. Blackboard is a software applications and services for learning that allow instructor in learning process by its provided functionality [16].

Authors in [13], [17], [18] and [19] compares Moodle and Blackboard in terms of communication tools, productivity tools, and students' involvement tools. As a result of their comparisons, Moodle is chosen as an optimal LMS based on architecture and technical aspects. Also, Moodle is an open source platform, cheaper and more flexible than Blackboard [20].

\subsection{Games}

Video games have been increasing their position in entertainment over time. These games are considered as activities with interaction feature that reserve the players challenges to involve them into an active process [21]. Games are defined as: "a system in which players engage in artificial conflict, defined by rules that result in a quantifiable outcome" [22].

\subsection{Game Based Learning}

Games have attracted the educators' attention to use it in the schools to support learning for a long time. This have led to a trend called Game-Based Leaning (GBL). Specific educational games used to apply GBL is called serious games.

Serious game are fully games with learning goal rather than just fun [23]. For example, In [24] authors have used interactive visualization and computer game to provide a web-based collaborative learning environment for teaching database analysis and design. The game units introduces the course topics to be explored. These units are hierarchically structured to allow students to dive for more details. Topics are 
hyperlinked for random browsing. Authors in [25] have described a computer game for teaching Software Engineering course. The software development cycle has been animated and the responsible person for each phase should take the best decision to complete the project. Team members that do the best project will take the higher marks.

Producing serious games with high quality requires large budgets [26]. Serious games needs a high quantity of resources, game knowledge and graphic design [27]. Also, it is costly in terms of money, time and effort [28].

So, an alternative way to GBL is to find the elements that make games fun and enjoyable then use them in learning process. So, the student will learn not by playing games but with the feeling of playing games [29].

Authors in [30] and [31] research about what makes computer games attractive to the players and how to use these aspects to improve student engagement in education.

\subsection{Gamification}

The motivational power of games is being penetrated in various non-game systems to keep users engaged with the systems and motivated to do a specific behavior. This is done through a gamification technique. The term "gamification" was emerged in October 2010 [29].

Gamification is defined as: the use of game elements for non-game systems [32]. Any system can be gamified by incorporating game elements into its activities to make it more engaged and motivating [33]. Werbach and Hunter [34] provided game element list and organized them into three levels of abstraction which are: dynamics, mechanics and components. The dynamics represent the big picture aspects such as: constraints, emotions, narrative, progression and relationship. Mechanics are processes that drive action forward such as: challenges, chance, competition, cooperation, feedback and reward. Components are the specific instantiations of mechanics and dynamics such as: points, levels, badges, avatar, achievement, content unlocking and leaderboards.

The main goal of gamification is rising users engagement with theses systems without undermining its credibility[35]. The target users of the gamified system are called players [29]. Gamification combined intrinsic motivations with extrinsic one to rise engagement [36]. Intrinsic motivations come when the user decides whether to make an action or not such as: competition, altruism, cooperation, sense of belonging, love and aggression. Extrinsic motivations happened when something leads the user to do an action such as: points, levels, badges, classifications, awards and missions.

Gamification is used in many context such as commerce, health, marketing, business, science, social networks, tourism and training [3]. Recently, gamification used in the education successfully to engage students in learning. Website like Khan Academy [37] and ClassDojo [38] are a clear examples of gamification used in e-learning.

\subsection{Gamification in e-Learning}

Engagement is identified as a valuable indicator of students' academic achievement [39]. When students engaged, they will be attracted to their work, continue their academic activities and challenge difficulties, and be pleasure for doing all of that [40].

From a pedagogical point of view, e-learning has a limitation that it does not transmit feelings nor motivate students as a teacher do [27]. Because this lack of emotion, e-learning systems must compensate students and motivate them in another way. Furthermore, the LMSs have a static feature and lack of usability and interactivity [41]. So, we need to a suitable way for improving LMS through improving the student's engagement and interaction with these systems.

This will be done by utilizing the new tools and techniques available to us [42]. Gamification can used here to achieve the main objectives of e-learning which are: high efficiency, engagement, satisfaction and 
motivation of learners [43].

Different methods were proposed to promote students' engagement using gamification. Monterraet al. in [44] proposed adding a fun layer to the learning system to make the learning process more engaged and motivating. This fun layer is peripheral so it could be plugged on any application without affecting the original system. They proposed implementing of the game elements such as leaderboards and badges in this layer to improve the student interaction with the LMS.

JB Fogg presents persuasive technology concept and how to use computers to change the user behavior [45]. He proposed Fogg's Behavior Model (FBM) which studies the factors that can lead to a certain behavior. FBM includes three main components when occurring at the same time they will lead to a certain behavior. These components are: motivation, ability and triggers. To trigger a desired behavior learners need to be motivated and able to solve the challenges at the same time. In [27] authors proposed using gamification to apply FBM to an e-learning system through offering points for correct answer and uncover the content progressively. So, using gamification in e-learning will triggers a more engaging behavior.

Raymer in [46] proposed that determining objectives, presenting feedback and rewarding are the basic elements of gamified learning system. Objectives should be divided to achievable steps that can be accomplished by using the students' skills and to keep them within their flow channel. Feedback is important to tell the students about their progress. Rewarding is useful to appreciate students effort.

Petrovic and Ivetic [47] proposed providing manageable tasks for learner to keep them within the flow channel and providing feedback and progress to raise their engagement. Also, they proposed including of social elements to promote competition between learners.

Nicholson [48] recommended focusing on including fun elements rather than scoring elements. Also, he proposed offering students different ways for achieving the wanted goal and give them the freedom for choosing their preferred way.

\section{Related Work}

This Section shows some related work that using gamification in e-learning, especially in higher education. A brief summery for each work is presented below.

Barata et al. [49] evaluated how gamification affects Master students by comparing a gamified course with a previous non-gamified version. Results showed an increasing in materials downloads, high participation and post to forums and a positive impact on attendance. No significant change in the grade average. Student feedback gathered through questionnaire conducted at the end of the course. They considered that the gamified course performed very well and it become more motivating and interesting.

A comparison between a game-based learning and a gamification technique was done by Jayasinghe and Dharmaratne [50] to determine which let students understand theories without any unnecessary decoration. Results showed that the students who have studied using the gamified components have obtained higher marks, more understanding of the theories and code than students who have studied using gaming component. Results of questionnaire showed that the gamified components are preferred by the students and it enable them to understand the theories rather than wasting their time to enjoy it with a full graphics game.

To increase student engagement, Berkling and Thomas [51] presented a setup for a gamified classroom through independent learning with many different choices, flexible speed and timing. Course topics are structured into areas and levels. Feedback regarding the gamification aspects was done through a survey. Results showed that students did not get the benefit of gamification in a positive way.

A gamified educative experience have designed by Domínguez et al. [52] for an e-learning platform to increase students' motivation. Gamification techniques were applied to the platform to support many areas 
such as cognitive area, emotional area and social area. Results showed that gamification have a great emotional and social impact on students by motivating them using rewards and leaderboard. Unfortunately, cognitive impact of gamification is not very significant over students according to overall score.

Todor and Pitică [53] showed an example of implementing the gamification concept in an e-learning platform to motivate students in continuous learning and to promote certain behaviors to be learned by them. Feedback was collected by observing students using the gamified e-learning platform. There was increasing in the interest for the course. The way the student showed their positive competitiveness was noticed, so the competition is a mean of progress for them.

An experiment was conducted by Akpolat and Slany in [54] where students should learn and use programming techniques while developing a software system. The results can be divided into two types: subjective and objective. Subjective results measured the perception of students through two online surveys: A mid-term evaluation and a final evaluation. Subjective results showed that students rated their learning as very good or good comparing with other non-gamified courses. Objective results measured the effect of gamification which resulted in a friendly competition between teams and high level of engagement.

Ibanez and Di-Serio [55] presented a case study to evaluate the use of gamification in learning. The study purpose was to explore the impact of gamification techniques on cognitive engagement of students. Pre-test and post-test questionnaire were used to measure the knowledge before and after the learning experience. Two other questionnaires were used to estimate reasons for getting involved in course activities and to identify students' focus during the learning experience. Results showed that students improved their knowledge after learning with the gamified platform and most students continued working even after earning the maximum points which indicates to students' cognitive engagement and their committing to learning.

Auvinen et al. [56] used achievement badges for rewarding student in the online learning environment. They also visualized student's behavior to give the student a feedback to help them being aware of their behavior. Results showed that visualization of students' behavior will increase the students' awareness of their behavior and then will increase their learning results. Feedback questionnaire was also used to collect students feedback about the gamified course.

An experiment was did by De-Marcos et al. [57] on undergraduate first year students to evaluate the effect of gamification on learning performance. They integrated a gamification plugin in the LMS. A comparison between this experimental group and the control group which used traditional e-learning is conducted. Results showed that gamification has a positive impact on learning performance.

The effect of game mechanics on cognitive and behavioral engagements of students was investigated by Hew et al. [58] through conducting two experiment studies among two semesters. In the two experiments, they employed experiment-control group design. Experiment group attend the gamified course while control group attended the same course but without game elements. Results showed a positive effect on student engagement but no difference on students knowledge.

The impact of gamification on learning performance and engagement was analyzed by Ortiz-Rojas et al. [59] through using badges for rewarding students who carried out mandatory tasks and optional activities. Programming tests was used to compare learning gain by students in control and experiment group. Engagement was determined by counting the optional activities carried out by the student. Results showed that gamification improved students' engagement but it has no impact on learning performance.

Zamora et al. [60] implemented a gamification technique in the learning process to improve the learning experience and motivate master degree students. Using gamification elements, researchers intended to motivate students to achieve their responsibilities in the course such as attendance, participations, presentations, seminars and exams. Results showed that gamification has a positive impact on learner's 
engagement.

Table 1 lists these works with details of courses, type of gamified component, gamification mechanics used, type of the search methodology, type of collected data and the effect of the gamification.

Table 1. Comparison of Related Work in Gamification

\begin{tabular}{|c|c|c|c|c|c|c|c|c|}
\hline $\begin{array}{l}\text { Pape } \\
\mathrm{r}\end{array}$ & Course & $\begin{array}{l}\text { Gamified } \\
\text { Component }\end{array}$ & $\begin{array}{l}\text { Mechanics } \\
\text { used }\end{array}$ & Methodology & $\begin{array}{l}\text { Collected } \\
\text { data }\end{array}$ & $\begin{array}{l}\text { Effect of } \\
\text { gamification }\end{array}$ & Outcome & $\begin{array}{l}\text { Study } \\
\text { Results }\end{array}$ \\
\hline \multirow[t]{2}{*}{ [49] } & \multirow{2}{*}{$\begin{array}{l}\text { Multimedia } \\
\text { Content } \\
\text { Production }\end{array}$} & \multirow{2}{*}{$\begin{array}{l}\text { E-learning } \\
\text { platform }\end{array}$} & \multirow{2}{*}{$\begin{array}{l}\text { Points, } \\
\text { Levels, } \\
\text { Challenges, } \\
\text { Leaderboar } \\
\text { d, } \\
\text { badges } \\
\end{array}$} & \multirow{2}{*}{$\begin{array}{l}\text { Quantitativ } \\
\text { e }\end{array}$} & Usage data & No difference & Behavioral & \multirow[t]{2}{*}{ Mixed } \\
\hline & & & & & $\begin{array}{l}\text { Questionnair } \\
\mathrm{e}\end{array}$ & $\begin{array}{l}\text { Increased } \\
\text { satisfaction }\end{array}$ & $\begin{array}{l}\text { Psychologic } \\
\text { al }\end{array}$ & \\
\hline \multirow[t]{3}{*}{ [50] } & \multirow{3}{*}{$\begin{array}{l}\text { Data Structure } \\
\text { and } \\
\text { Algorithms }\end{array}$} & \multirow{3}{*}{$\begin{array}{l}\text { E-learning } \\
\text { platform }\end{array}$} & \multirow[t]{3}{*}{ Ribbon } & \multirow{3}{*}{$\begin{array}{l}\text { Quantitativ } \\
\mathrm{e}\end{array}$} & Quiz mark & High mark & Behavioral & \multirow[t]{3}{*}{ Positive } \\
\hline & & & & & $\begin{array}{l}\text { Learning } \\
\text { time }\end{array}$ & Less quiz time & Behavioral & \\
\hline & & & & & $\begin{array}{l}\text { Questionnair } \\
\mathrm{e}\end{array}$ & $\begin{array}{l}\text { High } \\
\text { acceptance }\end{array}$ & $\begin{array}{l}\text { Psychologic } \\
\text { al }\end{array}$ & \\
\hline$[51]$ & $\begin{array}{l}\text { Software } \\
\text { Engineering }\end{array}$ & $\begin{array}{l}\text { Web } \\
\text { application }\end{array}$ & $\begin{array}{l}\text { Points, } \\
\text { Levels, } \\
\text { Rewards, } \\
\text { Progress } \\
\text { bar, } \\
\text { Leaderboar } \\
\text { d }\end{array}$ & $\begin{array}{l}\text { Quantitativ } \\
\text { e }\end{array}$ & $\begin{array}{l}\text { Questionnair } \\
\text { e }\end{array}$ & $\begin{array}{l}\text { No } \\
\text { engagement }\end{array}$ & $\begin{array}{l}\text { Psychologic } \\
\text { al }\end{array}$ & $\begin{array}{l}\text { Negativ } \\
\mathrm{e}\end{array}$ \\
\hline \multirow[t]{2}{*}{ [52] } & \multirow[t]{2}{*}{$\begin{array}{l}\text { Qualification } \\
\text { for users of } \\
\text { ICT }\end{array}$} & \multirow[t]{2}{*}{$\begin{array}{l}\text { E-learning } \\
\text { platform }\end{array}$} & \multirow[t]{2}{*}{$\begin{array}{l}\text { Leaderboar } \\
\text { d, } \\
\text { Badges }\end{array}$} & \multirow[t]{2}{*}{$\begin{array}{l}\text { Quantitativ } \\
\text { e }\end{array}$} & Marks & $\begin{array}{l}\text { High scores in } \\
\text { practical } \\
\text { assignment, } \\
\text { Low scores in } \\
\text { written } \\
\text { assignment }\end{array}$ & Behavioral & \multirow[t]{2}{*}{ Mixed } \\
\hline & & & & & $\begin{array}{l}\text { Questionnair } \\
\text { e }\end{array}$ & $\begin{array}{l}\text { High } \\
\text { motivation }\end{array}$ & $\begin{array}{l}\text { Psychologic } \\
\text { al }\end{array}$ & \\
\hline [53] & Electronics & $\begin{array}{l}\text { E-learning } \\
\text { platform }\end{array}$ & $\begin{array}{l}\text { Points, } \\
\text { Avatar, } \\
\text { Progress, } \\
\text { Feedback, } \\
\text { Leaderboar } \\
\text { d, } \\
\text { Rewards, } \\
\text { Badges }\end{array}$ & Qualitative & Observation & $\begin{array}{l}\text { Improved } \\
\text { competence, } \\
\text { Increased } \\
\text { interesting }\end{array}$ & $\begin{array}{l}\text { Psychologic } \\
\text { al }\end{array}$ & Positive \\
\hline \multirow[t]{2}{*}{ [54] } & \multirow[t]{2}{*}{$\begin{array}{l}\text { Software } \\
\text { Engineering }\end{array}$} & \multirow[t]{2}{*}{$\begin{array}{l}\text { E-learning } \\
\text { platform }\end{array}$} & \multirow{2}{*}{$\begin{array}{l}\text { Weekly } \\
\text { challenge } \\
\text { cup, } \\
\text { High score } \\
\text { list }\end{array}$} & \multirow[t]{2}{*}{$\begin{array}{l}\text { Quantitativ } \\
\mathrm{e}\end{array}$} & Survey & $\begin{array}{l}\text { High rated } \\
\text { learning }\end{array}$ & Behavioral & \multirow[t]{2}{*}{ Positive } \\
\hline & & & & & $\begin{array}{l}\text { Usage of } \\
\text { programmin } \\
\text { g practices }\end{array}$ & $\begin{array}{l}\text { High } \\
\text { interesting, } \\
\text { High } \\
\text { engagement, } \\
\text { Friendly } \\
\text { competition }\end{array}$ & $\begin{array}{l}\text { Psychologic } \\
\text { al }\end{array}$ & \\
\hline
\end{tabular}




\begin{tabular}{|c|c|c|c|c|c|c|c|c|}
\hline \multirow[t]{2}{*}{ [55] } & \multirow[t]{2}{*}{$\begin{array}{l}\text { C-Programmi } \\
\text { ng }\end{array}$} & \multirow[t]{2}{*}{$\begin{array}{l}\text { E-learning } \\
\text { platform }\end{array}$} & \multirow[t]{2}{*}{$\begin{array}{l}\text { Points, } \\
\text { Leaderboar } \\
\text { d, } \\
\text { Badges }\end{array}$} & \multirow[t]{2}{*}{$\begin{array}{l}\text { Quantitativ } \\
\text { e }\end{array}$} & $\begin{array}{l}\text { Pre-test } \\
\text { Post-test }\end{array}$ & $\begin{array}{l}\text { Increased } \\
\text { comprehensio } \\
\text { n, } \\
\text { High points }\end{array}$ & Behavioral & \multirow[t]{2}{*}{ Positive } \\
\hline & & & & & $\begin{array}{l}\text { Questionnair } \\
\text { e }\end{array}$ & $\begin{array}{l}\text { High } \\
\text { engagement }\end{array}$ & $\begin{array}{l}\text { Psychologic } \\
\text { al }\end{array}$ & \\
\hline \multirow[t]{2}{*}[56]{} & \multirow[t]{2}{*}{$\begin{array}{l}\text { Data Structure } \\
\text { and algorithm }\end{array}$} & \multirow{2}{*}{$\begin{array}{l}\text { Online } \\
\text { learning } \\
\text { environme } \\
\text { nt }\end{array}$} & \multirow{2}{*}{$\begin{array}{l}\text { Achievemen } \\
\text { t, } \\
\text { Badges, } \\
\text { Visualized } \\
\text { feedback } \\
\end{array}$} & \multirow[t]{2}{*}{$\begin{array}{l}\text { Quantitativ } \\
\text { e }\end{array}$} & $\begin{array}{l}\text { Exercise } \\
\text { points }\end{array}$ & $\begin{array}{l}\text { High exercise } \\
\text { points }\end{array}$ & Behavioral & \multirow[t]{2}{*}{ Positive } \\
\hline & & & & & Survey & $\begin{array}{l}\text { Increased } \\
\text { engagement }\end{array}$ & $\begin{array}{l}\text { Psychologic } \\
\text { al }\end{array}$ & \\
\hline \multirow[t]{3}{*}{ [57] } & \multirow{3}{*}{$\begin{array}{l}\text { Qualification } \\
\text { for ICT users }\end{array}$} & \multirow[t]{3}{*}{ LMS } & \multirow{3}{*}{$\begin{array}{l}\text { Trophies, } \\
\text { Badges, } \\
\text { Challenges, } \\
\text { Leaderboar } \\
\text { d }\end{array}$} & \multirow{3}{*}{$\begin{array}{l}\text { Quantitativ } \\
\text { e }\end{array}$} & Pre-test & No difference & Behavioral & \multirow[t]{3}{*}{ Mixed } \\
\hline & & & & & $\begin{array}{l}\text { Assignment } \\
\text { marks }\end{array}$ & High marks & Behavioral & \\
\hline & & & & & $\begin{array}{l}\text { Final exam } \\
\text { mark }\end{array}$ & Low marks & Behavioral & \\
\hline \multirow[t]{3}{*}{ [58] } & \multirow{3}{*}{$\begin{array}{l}\text { Designing } \\
\text { Questionnaire }\end{array}$} & \multirow[t]{3}{*}{ LMS } & \multirow{3}{*}{$\begin{array}{l}\text { Points, } \\
\text { Badges, } \\
\text { Leaderboar } \\
\text { d }\end{array}$} & \multirow{3}{*}{$\begin{array}{l}\text { Quantitativ } \\
\text { e }\end{array}$} & Pre-test & No difference & Behavioral & \multirow[t]{3}{*}{ Mixed } \\
\hline & & & & & Post-test & No difference & Behavioral & \\
\hline & & & & & $\begin{array}{l}\text { Questionnair } \\
\mathrm{e}\end{array}$ & $\begin{array}{l}\text { High } \\
\text { motivation }\end{array}$ & $\begin{array}{l}\text { Psychologic } \\
\text { al }\end{array}$ & \\
\hline \multirow[t]{2}{*}{ [59] } & \multirow[t]{2}{*}{$\begin{array}{l}\text { Computer } \\
\text { Programming }\end{array}$} & \multirow[t]{2}{*}{$\begin{array}{l}\text { LMS, } \\
\text { Web based } \\
\text { application }\end{array}$} & \multirow[t]{2}{*}{ Badge } & \multirow[t]{2}{*}{$\begin{array}{l}\text { Quantitativ } \\
\text { e }\end{array}$} & $\begin{array}{l}\text { Programmin } \\
\text { g Test }\end{array}$ & $\begin{array}{l}\text { No impact on } \\
\text { learning } \\
\text { performance }\end{array}$ & Behavioral & \multirow[t]{2}{*}{ Mixed } \\
\hline & & & & & $\begin{array}{l}\text { No. of } \\
\text { optional } \\
\text { activities } \\
\text { done }\end{array}$ & $\begin{array}{l}\text { High } \\
\text { engagement }\end{array}$ & $\begin{array}{l}\text { Psychologic } \\
\text { al }\end{array}$ & \\
\hline [60] & Economics & $\begin{array}{l}\text { Mobile } \\
\text { application }\end{array}$ & $\begin{array}{l}\text { Points, } \\
\text { Levels, } \\
\text { Leaderboar } \\
\text { d }\end{array}$ & Qualitative & Observation & $\begin{array}{l}\text { Increased } \\
\text { engagement }\end{array}$ & $\begin{array}{l}\text { Psychologic } \\
\text { al }\end{array}$ & Positive \\
\hline
\end{tabular}

\section{System Design}

This section describes data structure DS course and the components included in the system to gamifying the data structure course.

\subsection{Data Structure Course}

Data Structure Course is a mandatory bachelor course in Computer Science department. It covers the standard data structures such as binary tree, linked list, stack, queue and recursion. Many students considered that it is difficult to understand and it lacks interest and ability of innovation [61]. Many students claimed that learning data structure is a complex issue because it has an abstract nature and needs high skills of problem solving [62].

Different methods were used to teach data structure course to make it easy and understandable. One of the common methods is visualization [62] which translate data structure concepts into organized visual forms to portray the algorithm processes dynamics over time. Static visualization are used previously in textbooks where concepts are explained by static illustration with codes, flowcharts and explanation texts. Then, animated visualization appears to deliver a dynamic representation of course contents [63]. 
Surprisingly, authors in [62] and [64] found that visualization is not significant and cannot be a standard method in data structure learning. The animated visualization has evolved to interactive visualization which leads to deep understanding of the concepts [65], [66]. Although that interactive visualization has a great impact on learning but it has a weakness in engaging students continuously, frequently and actively [65]. This leads to using serious games to teach data structure because it is not only interactive but also it engages students to learn continuously [67], [68]. The game based learning is effective but it used advanced techniques and may lose the primary goal of learning process. So we need to more formal approach that maintains the seriousness of the educational process in addition to make the course more interesting and motivating. This can be achieved by using gamification technique.

\subsection{Gamifying the DS Course}

Rather than achieving the goals of the course and its students through extrinsic motivation such as: grades and points, we try to amplify the intrinsic motivation through gamification [69]. To achieve this, we have to improve the students' sense of competence, autonomy and relatedness which are three basic elements of intrinsic motivation [70]. According to Self-Determination Theory (SDT), satisfying these three psychological needs will enhance the self-motivation [71].

Przybylski et al. [72] suggested that the attractiveness of video games is come from their ability to satisfy these three psychological needs. They proposed a motivational model based on SDT to discover how video games satisfy these psychological needs. For example: 1) using feedback and showing progress will satisfy the competence feeling, 2) providing choices of strategies and opportunities will satisfy the sense of autonomy and 3) competition in the leaderboard and cooperation in the forum will satisfy the relatedness.

In order to make the course more engaging and interesting, we gamified it by balancing between graphical design and persuasive design [73]. Graphical dimension concerns the visual aspects of the interface to be attractive and legible while keeping its professional and formal appearance. This have been achieved through a clear user interface, using theme, different fonts, colors and global layout [73].

Persuasive dimension concerns the game elements to be incorporated to the system. Game elements used in our study and the reasons of its inclusion in the course are listed in Table 2.

Table 2. Gamification Elements and Purpose of Its Use in the Course

\begin{tabular}{|l|l|}
\hline \multicolumn{1}{|c|}{ Game element } & \multicolumn{1}{|c|}{ Purpose } \\
\hline $\begin{array}{l}\text { Avatar, Options in selecting } \\
\text { topics, Options in determining } \\
\text { badges }\end{array}$ & To satisfy the autonomy need according to SDT [71] \\
\hline $\begin{array}{l}\text { Splitting course content in } \\
\text { smaller topics }\end{array}$ & $\begin{array}{l}\text { Splitting the overall objective into achievable steps is a key component } \\
\text { in gamified system developing [47] }\end{array}$ \\
\hline Levels & $\begin{array}{l}\text { To satisfy the competence need according to SDT [71] } \\
\text { To keep students within the flow by providing manageable tasks[48] }\end{array}$ \\
\hline Closed levels & To open content progressively based on [27] \\
\hline $\begin{array}{l}\text { Points, Badges, Progress, } \\
\text { Challenges }\end{array}$ & To satisfy the competence need according to SDT [71] \\
\hline Feedback & $\begin{array}{l}\text { To satisfy the competence need according to SDT [71] } \\
\text { To avoid loss or confusing based on [46] }\end{array}$ \\
\hline Leaderboard & $\begin{array}{l}\text { To satisfy the competence need according to SDT [71] } \\
\text { To satisfy the relatedness need according to SDT [71] }\end{array}$ \\
\hline Forum, Chatting & To satisfy the relatedness need according to SDT [71] \\
\hline External resources & To introduce fun element[48] \\
\hline
\end{tabular}




\begin{tabular}{|l|l|}
\hline & To satisfy the autonomy need according to SDT [71] \\
\hline Videos tutorial & $\begin{array}{l}\text { To introduce fun element[48] } \\
\text { To satisfy the autonomy need according to SDT [71] }\end{array}$ \\
\hline
\end{tabular}

\section{System Implementation}

The course was built on Moodle LMS. Data structure content was uploaded to the course. Interface was designed to be attractive and legible while keeping its professional and formal appearance. Game elements were added. Accounts for students were created.

When a student login to the gamified course using her account, she can edit her profile and upload her own avatar. Fig. 1 showed the profile page of the student.

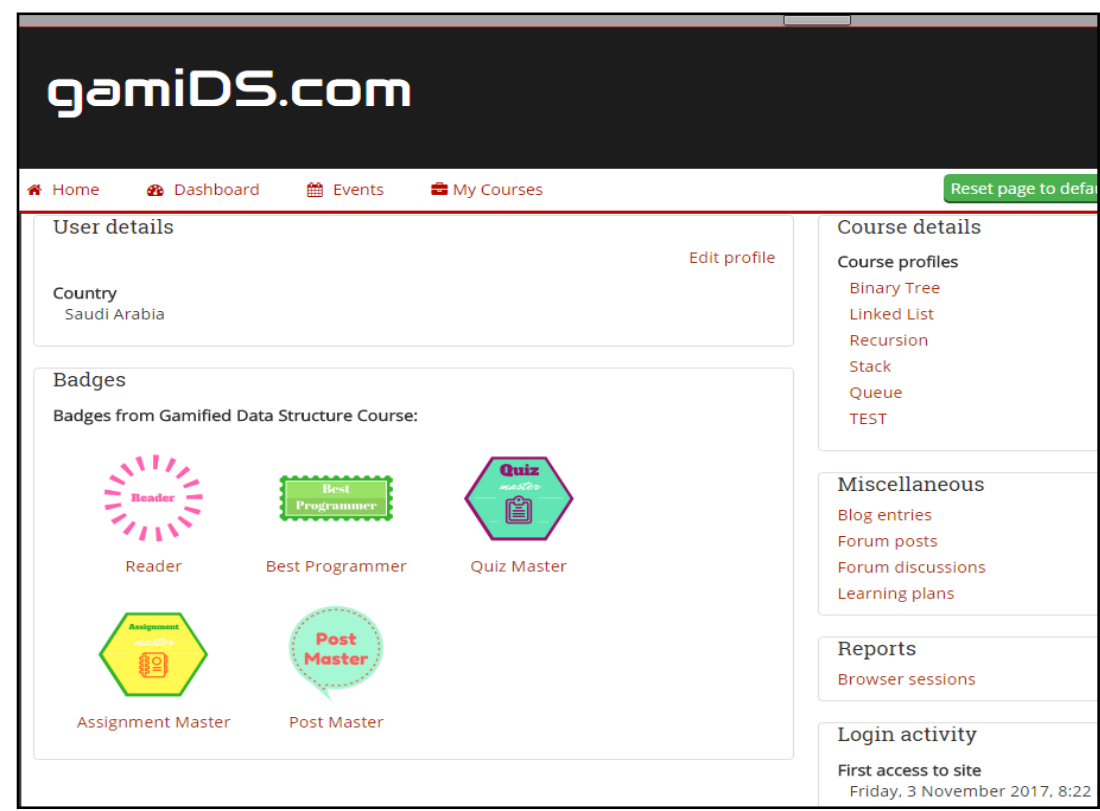

Fig. 1. Profile page.

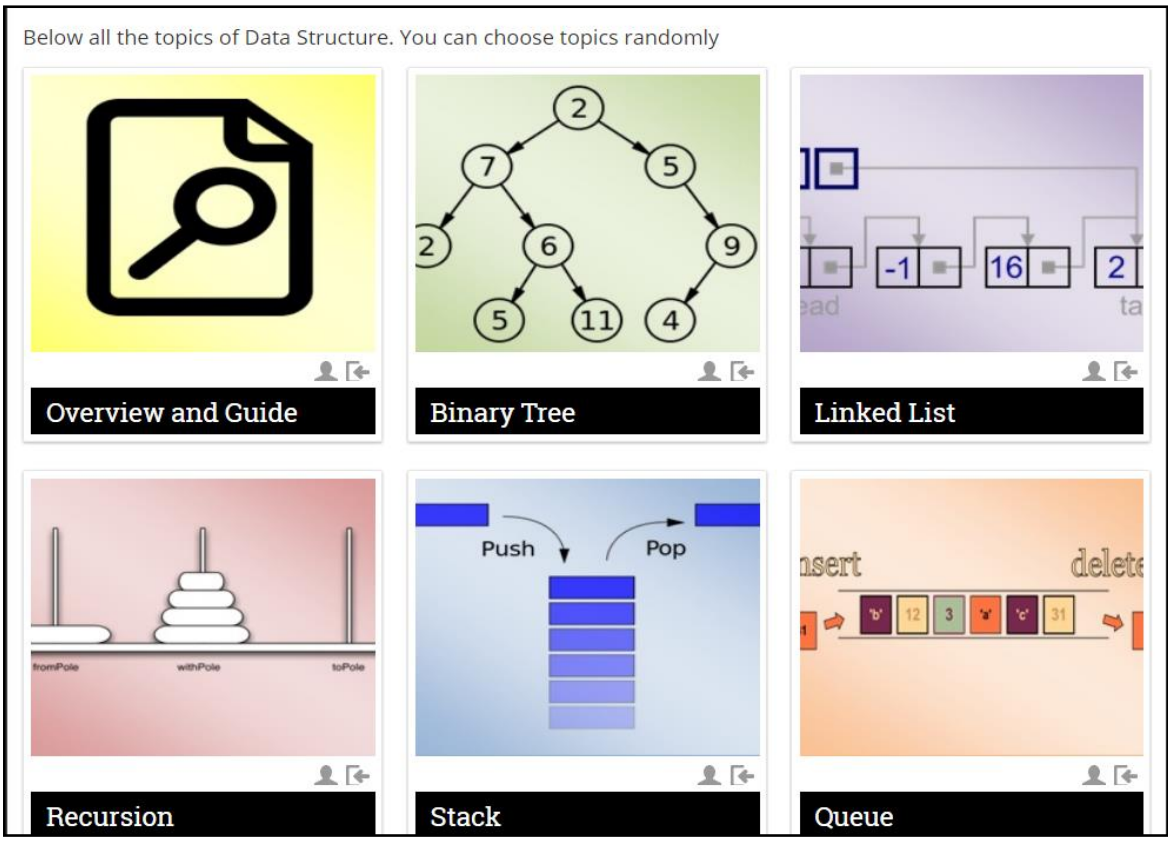

Fig. 2. Gamified course interface. 
In the course main interface the data structure course is divided into main topics (binary tree, linked list, recursion, stack and queue) where the student can choose any topic to learn first. The course interface is shown in Fig. 2.

Each course topic was divided into levels starting from level 1 (topic fundamental) until highest level (practice problems). The course topics content will uncovered progressively, so student cannot reach a level unless finishing the previous level. Open and closed levels are shown in Fig. 3.

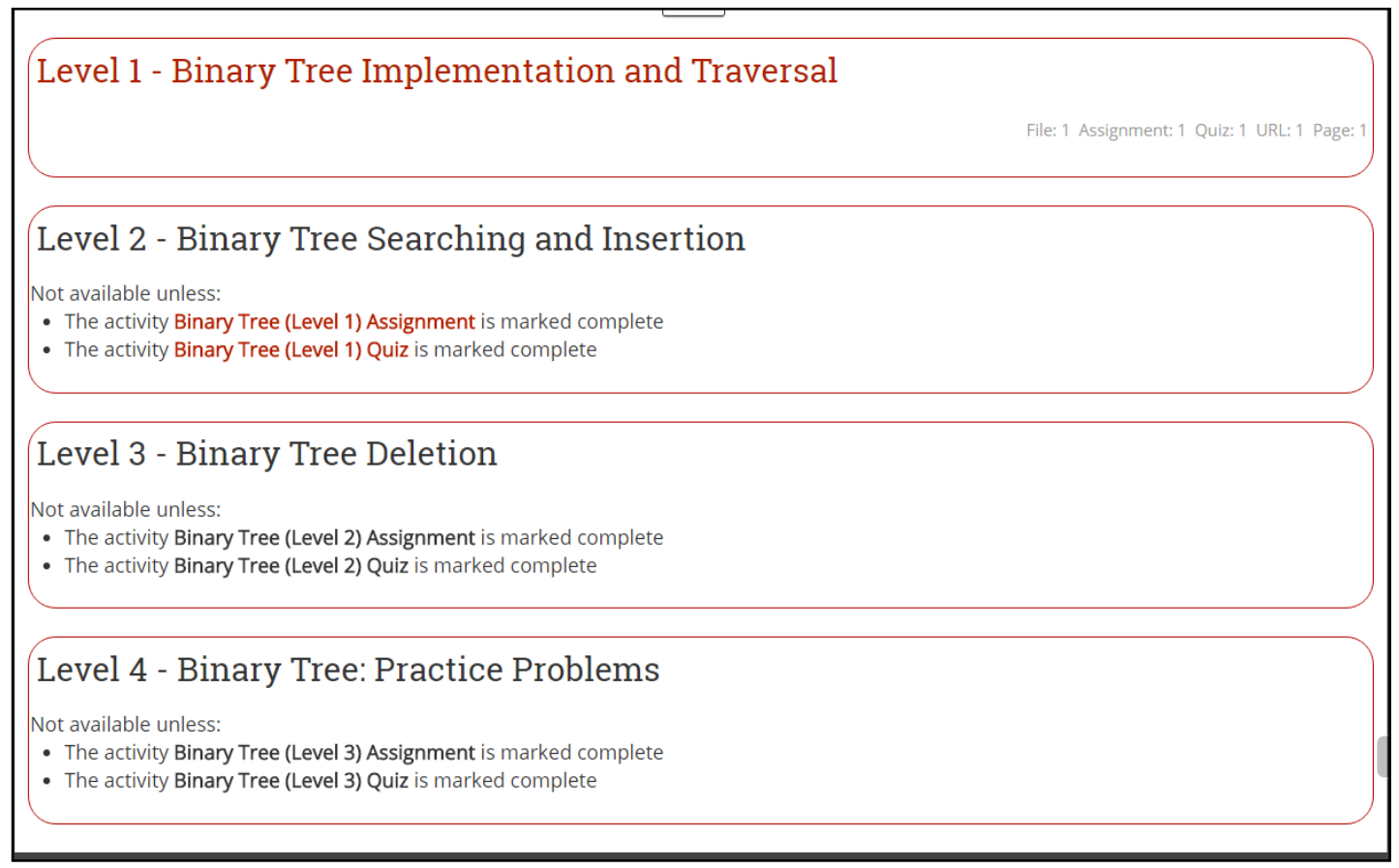

Fig. 3. Open and closed levels in binary tree topic.

There are many activities in the course, some are mandatory and the others are optional. Student will earn points when completing mandatory activities like assignment and quizzes. Extra points were given to student if she do any of the optional activities such as reading the external resources, post or reply to forum, helping classmates through answering their question or review their codes. For each topic, there is links to external resources for helping student to find the suitable materials and take the most of the topic. Also, a video tutorial was included in each topic for making student more understanding through audio and visual experience. Course activities of binary tree topic are shown in Fig. 4.

Student can take a badge for each achievement she did whether it is based on mandatory or optional activities. Student has a choice of determining which achievement she want to achieve to get badges and extra points for leveling up. Examples of badges and their associated achievement is presented in Fig. 5.

Feedback is offered constantly to show the student progress within the course through points and received badges. Points and badges will affect student's status directly and this will be shown in the badges section and in the leaderboard. Badges section appears in the front page of the course, so student can see all badges she have achieved as shown in Fig. 6 .

Leaderboard shows the highest five students in each topic. It displays students by row sorted in descending order by points. Leaderboard provides a progress to the student and encourage competition among them when they see others rank. A screenshot of leaderboard is shown in Fig. 7.

Some challenges were added to each topic to improve student's skills. Challenging contains programming problems sorted by their difficulty level. When student can solve these problems, she will have a high rate of 
problem solving and overcoming failure skills. Some challenging is shown in Fig. 8.

Social aspects appear in forum and chatting. Through forum, students can post topics and reply to others' topics to share their opinions and experiences. Also, student can help their classmates by answering their questions and review their programming codes. Chatting feature allows student to communicate with each other flexibly. Fig. 9 shows the forum posts.

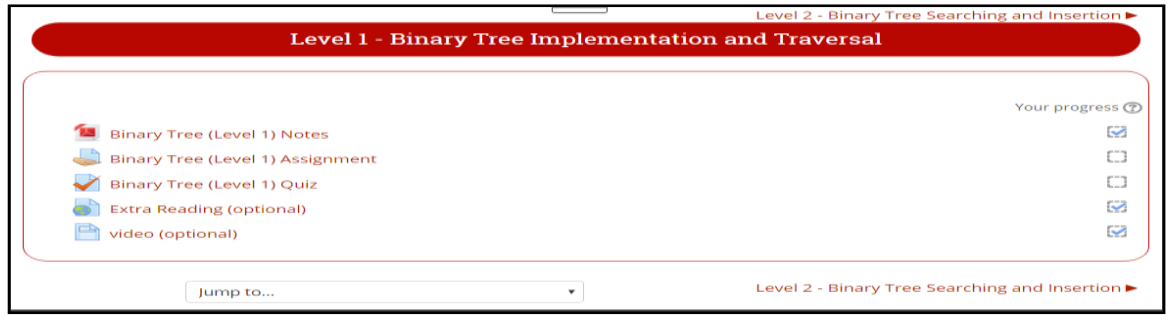

Fig. 4. Binary tree mandatory and optional activities.

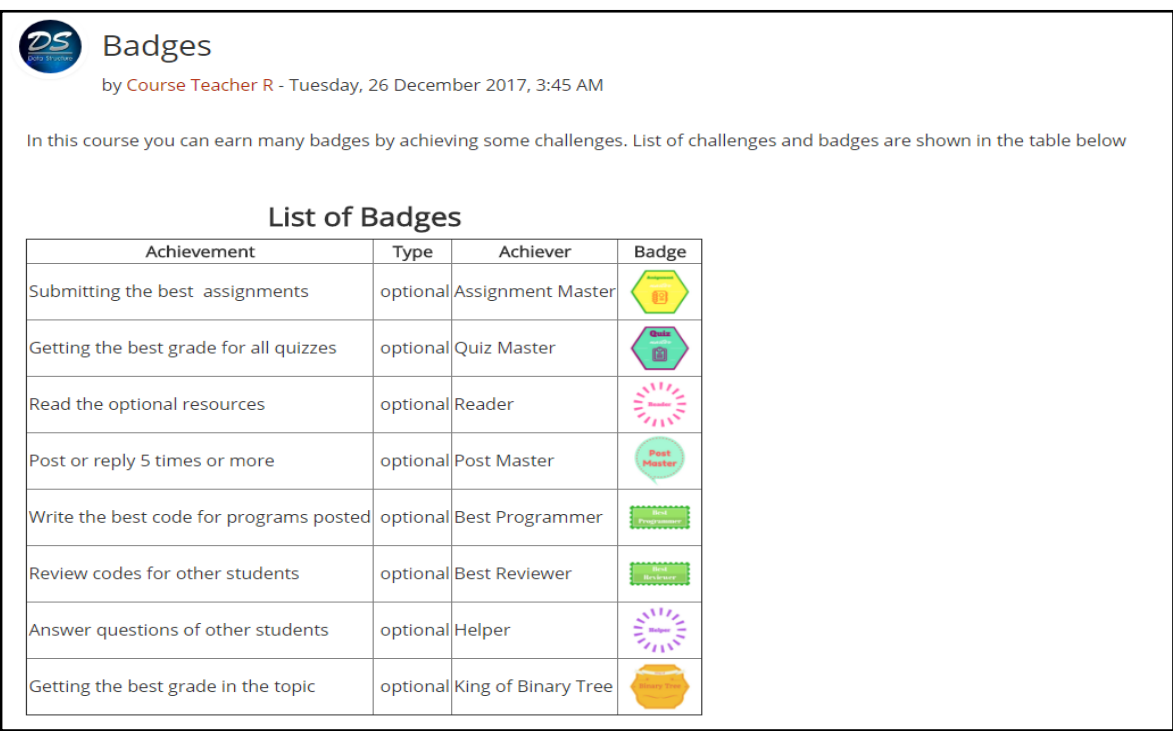

Fig. 5. Badges and achievements.

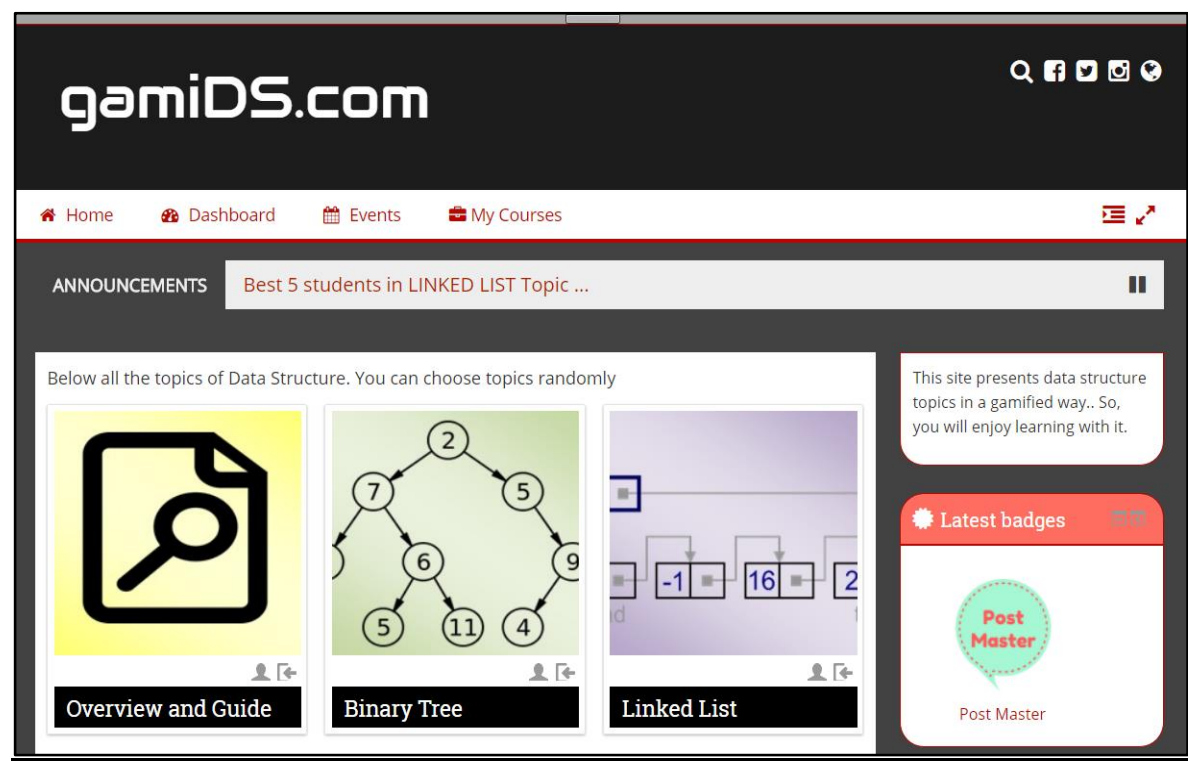

Fig. 6. Collected badges are shown in badge section on the bottom right of the screen. 


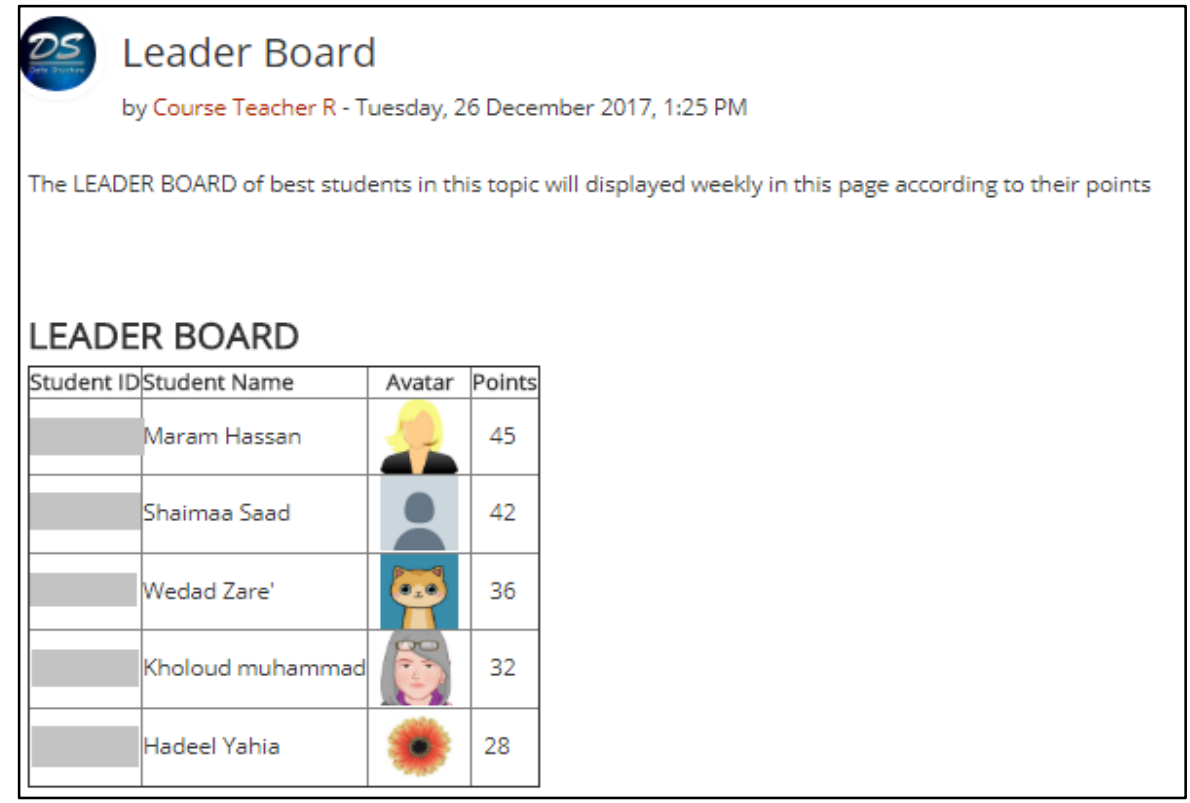

Fig. 7. A screenshot of the leaderboard.

\section{Binary Tree Challenges}

Here you will find programming challenges.

This is a question and answer forum. In order to see other responses to these questions, you must first post your answer

\section{Add a new question}

Discussion

Started by

Challenge 1: The Soap Mystery

Challenge 2: Sumit and Chocolates

Challenge 3: Simple Game

\begin{tabular}{|cccr} 
DS Course Teacher R & 3 & Tue, 26 Dec 2017, 1:13 PM \\
\hline DS & Course Teacher R & 2 & Tue, 26 Dec 2017, 1:12 PM \\
DS Course Teacher R & 1 & Tue, 26 Dec 2017, 1:11 PM
\end{tabular}

Fig. 8. Challenges page.

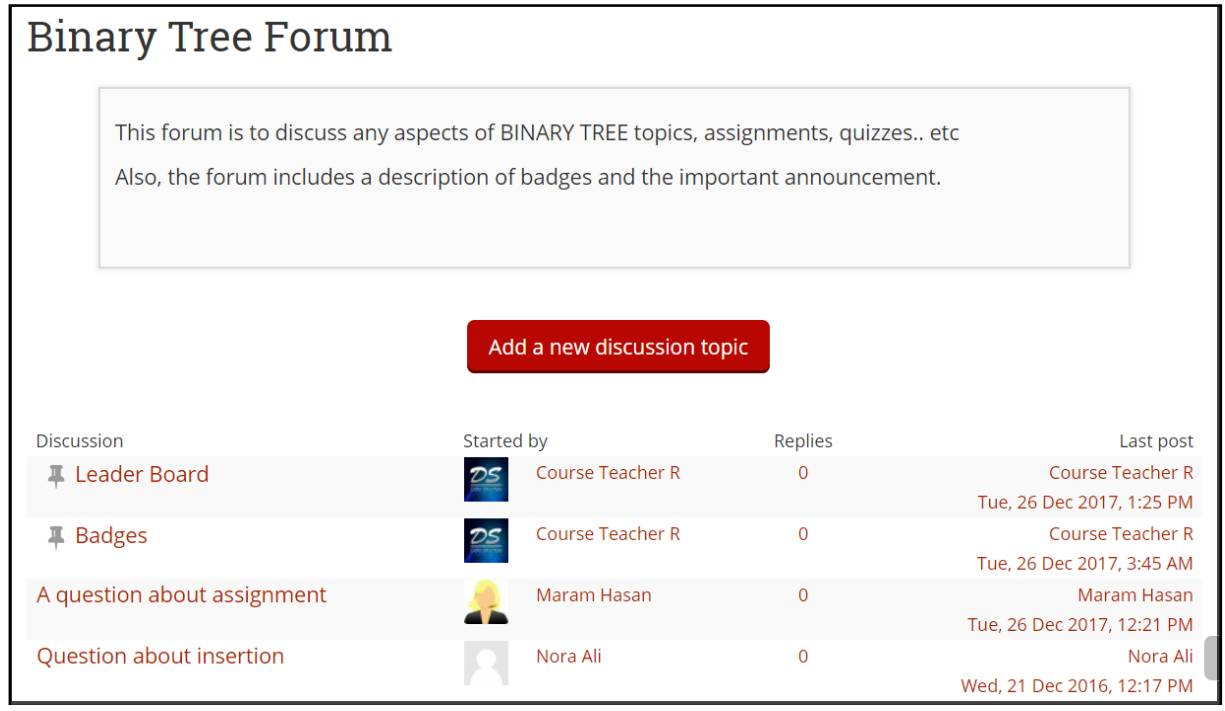

Fig. 9. The forum. 


\section{Experimental Study}

To evaluate the effectiveness of the gamified course, an experiment was conducted for 40 students of data structure course. Initially we introduced the goal of the experiment to the students. Then we explained the course content and illustrated the idea of gamification. We gave them a detailed description of how to use the gamified course to let them get the most of learning experience.

First, students have to login to the gamified course and complete the pre-test. Pre-test is developed to measure their initial knowledge about data structure concepts. It covers the basic topics of data structure. Then, students have to navigate the course and do its activities while using gamification features implemented in the course. Finally, Student have to do the post-test to measure the effectiveness of the gamification on her learning outcome.

Pre-test and post-test will used to compare the learning performance of students before and after the gamification experience. Also, students asked to fill online questionnaire about their feedback regarding their experience. Questionnaire will used to measure student engagement.

\section{Results and Discussion}

Collected data that resulted from the experiment will presented and discussed in this section. For facilitating the statistical analysis, points were normalized in the range 0-100.

\subsection{Effect of Gamification on Learning Performance}

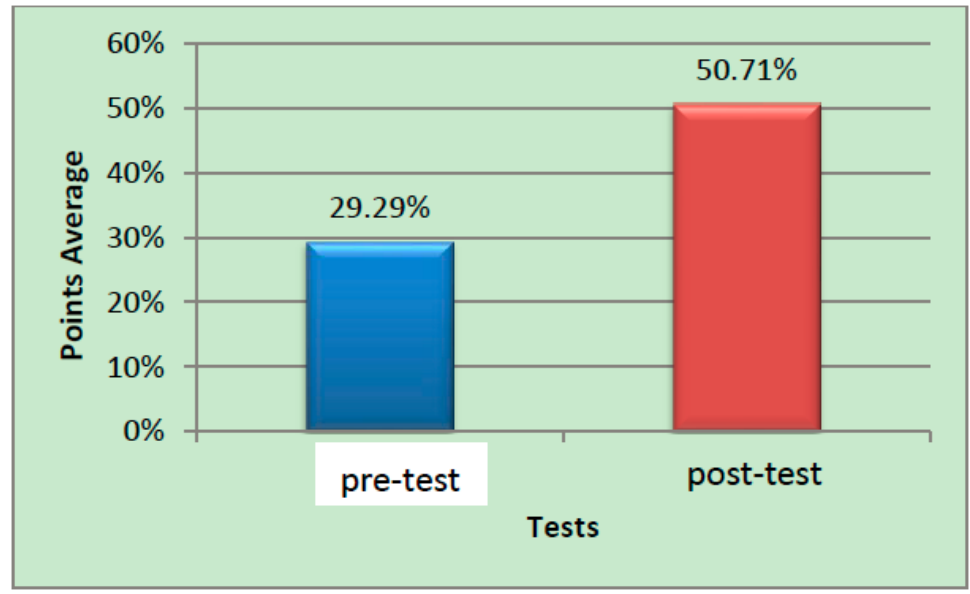

Fig. 10. Average of points for pre-test and post-test.

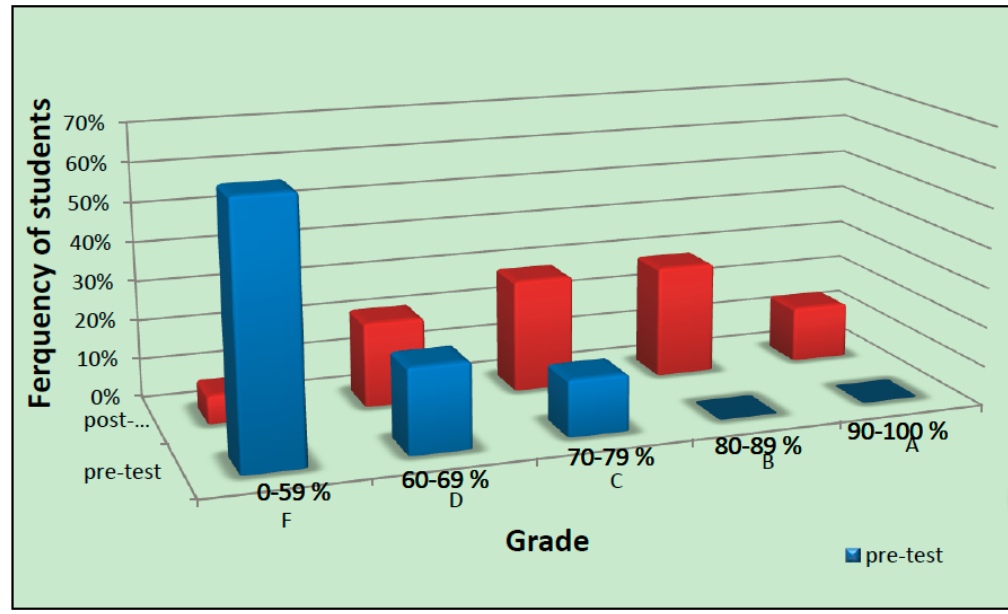

Fig. 11. Point distribution of students in pre-test and post-test. 
Fig. 11. shows the point distribution of students before and after the experiment. Before the gamification experience, more than half of students (64\%) failed the test. The rest (35\%) got grade $\mathrm{C}$ and D. No student got high grades. After the gamification experience, just $7 \%$ of student failed the test and $21 \%$ of student got grade $D$. The same percent of student (29\%) got grade $C$ and B, $14 \%$ got grade $A$.

To evaluate the effectiveness of gamification on students' learning performance, we will compare the results of pre-test and post-test. Fig. 10 shows that the points average of pre-test was $29.29 \%$ whereas points average of post-test was $50.71 \%$ which means that students get more points after the gamification experience. This result indicates that gamification has a positive impact on learning performance .

\subsection{Effect of Gamification on Student Engagement}

The students were asked to answer a questionnaire to measure their engagement in the gamified course. The questionnaire contains nine statement and it based on a five-point Likert scale. Question statements and student's answers are summarized in Table 3.

Table 3. Engagement Questionnaire Results

\begin{tabular}{|l|c|c|c|c|c|}
\hline Question statement & Strongly disagree & Disagree & $\begin{array}{c}\text { Neither agree nor } \\
\text { disagree }\end{array}$ & Agree & Strongly agree \\
\hline $\begin{array}{l}\text { I enjoyed the gamified course } \\
\text { experience }\end{array}$ & $0.00 \%$ & $5.56 \%$ & $5.56 \%$ & $27.78 \%$ & $61.11 \%$ \\
\hline $\begin{array}{l}\text { I feel that the gamified course design } \\
\text { was attractive }\end{array}$ & $5.56 \%$ & $0.00 \%$ & $5.56 \%$ & $61.11 \%$ & $27.78 \%$ \\
\hline $\begin{array}{l}\text { The course content was presented } \\
\text { effectively? }\end{array}$ & $0.00 \%$ & $0.00 \%$ & $11.11 \%$ & $50.00 \%$ & $38.89 \%$ \\
\hline $\begin{array}{l}\text { Using the course material was easy } \\
\text { for me }\end{array}$ & $0.00 \%$ & $5.56 \%$ & $11.11 \%$ & $33.33 \%$ & $50.00 \%$ \\
\hline $\begin{array}{l}\text { I learned about the course topics } \\
\text { easily }\end{array}$ & $0.00 \%$ & $0.00 \%$ & $50.00 \%$ & $27.78 \%$ & $22.22 \%$ \\
\hline I feel engaged in this course & $0.00 \%$ & $0.00 \%$ & $16.67 \%$ & $38.89 \%$ & $44.44 \%$ \\
\hline $\begin{array}{l}\text { The gamified course enhance my } \\
\text { motivation }\end{array}$ & $0.00 \%$ & $0.00 \%$ & $27.78 \%$ & $22.22 \%$ & $50.00 \%$ \\
\hline $\begin{array}{l}\text { I like the gamification elements that } \\
\text { added to the course }\end{array}$ & $0.00 \%$ & $0.00 \%$ & $5.56 \%$ & $50.00 \%$ & $44.44 \%$ \\
\hline I like to gamify the other courses & $0.00 \%$ & $0.00 \%$ & $44.44 \%$ & $44.44 \%$ & $11.11 \%$ \\
\hline
\end{tabular}

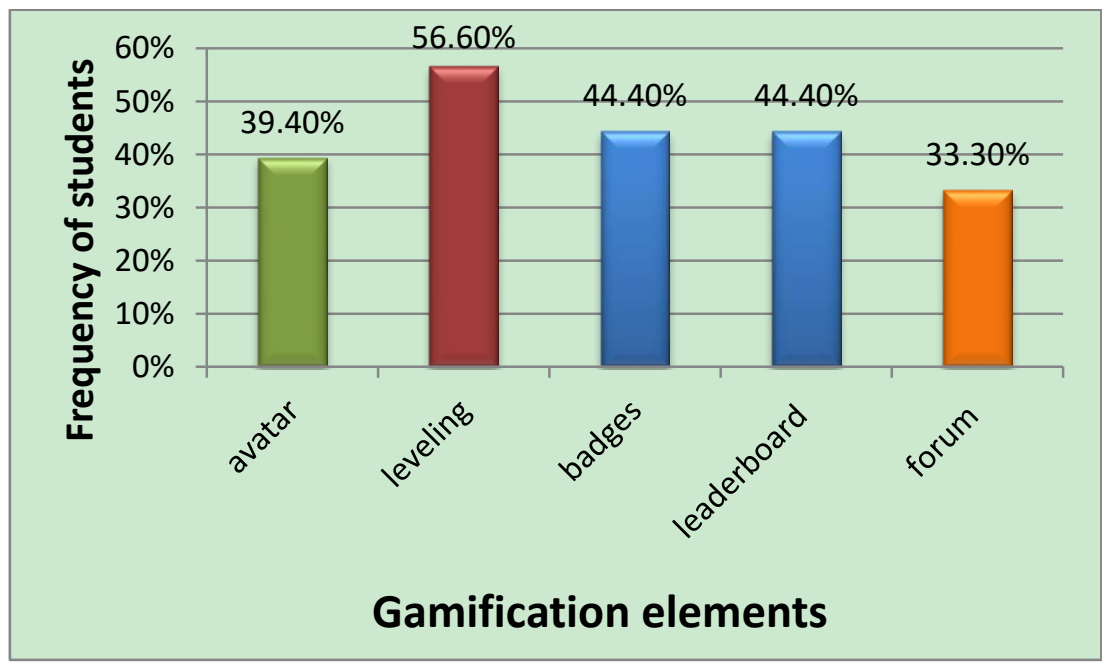

Fig. 12. Preferred gamification elements. 
We can see that $88.89 \%$ of students were strongly agree or agree that they enjoyed the gamified course experience. About the gamified course, $61.11 \%$ agree that its design was attractive, $50 \%$ of students believe that course content was presented effectively and its material was easy o use.

Most of the student felt engaged in the course (44.44 \%) and their motivation was enhanced (50\%). Half of the student (50\%) liked the added gamification elements but just $44.44 \%$ like to gamify the other courses.

Also, students were asked to choose the most interesting gamification feature. Results are shown in Fig. 12. Result shows that $56 \%$ of student found that leveling is the most interesting feature followed by badges and leaderboard with rate of $44.4 \%$, followed by avatars with rate of $39.4 \%$, and finally is the forum with rate of $33.3 \%$.

\section{Conclusion and Future Work}

Gamification is the use of game elements in non-game systems. It used in e-learning to increase the effectiveness of learning process and make it more interesting. An experiment was conducted to evaluate the effectiveness of gamification on students' learning performance and engagement. Pre-test and post-test were used to compare the results of student before and after the gamification experience. Results showed that gamification has a positive impact on learner through increasing in their marks. Also a questionnaire was used to measure the student engagement. Results showed that gamification make the students interesting and more engaged.

Our future work will try to measure student's engagement through tracing their behavior through the course not just from their self-reported questionnaire. Analyze student engagement will be done through using more scientific methods for measuring engagement such as sequential pattern mining.

\section{References}

[1] Schell, J. (2008). The art of game design: A book of lenses. Ann. Phys., 54, 489.

[2] Hunicke, R., Leblanc, M., \& Zubek, R. (2004). MDA: A formal approach to game design and game research. Discovery, 83(3), 1-5.

[3] Hamari, J., Koivisto, J., \& Sarsa, H. (2014). Does gamification work? - A literature review of empirical studies on gamification. Proceedings of the 47th Hawaii International Conference on System Science.

[4] Gee, J. P. (2003). What video games have to teach us about learning and literacy. Hampshire, England, U.K.: Palgrave Macmillan, 256.

[5] Kolowich, S. (2013). The Chronicle. Retrieved from the website: http://chronicle.com/blogs/wiredcampus/universities-try-mooc2degree-courses-to-luresuccessful students-to-online-programs/41829

[6] Sun, P. C., Tsai, R. J., Finger, G., Chen, Y. Y., \& Yeh, D. What drives a successful e-Learning? An empirical investigation of the critical factors influencing learner satisfaction. Computers \& Education, 50(1183-1202).

[7] Higher Education Funding Council of England. (2005). HEFCE Strategy for e-Learning.

[8] Normark, O. R., \& Cetindamar, D. (2005). E-learning in a competitive firm setting. Innovations in Education \& Teaching International, 42(4), 325-335.

[9] Draves, W. A. (2007). Advanced Teaching Online. Wisconsin: Learn.

[10] Ellis, R. K. (2009). A field guide to learning management systems. American Society for Training and Development.

[11] Hall, B. (2004). E-Learning Guidebook: Six Steps to Implementing ELearning. Brandon-Hall.Com, Sunnyvale, Calif, USA. 
[12] Bickford, A. (2013). 12 Common Complaints about Learning Management Systems (LMS). Retrieved from the website: http://connectthinking.com.au/12 common-complaints-about-learning-management-systems-lms/

[13] Subramanian, P., Zainuddin, N., Alatawi, S., Javabdeh, T., \& Hussin, A. R. C. (2014). A study of comparison between moodle and blackboard based on case studies for better LMS. Journal of Information Systems Research and Innovation.

[14] Top 20 LMS software 2017 - Compare reviews. Capterra.com. Retrieved from the website: https://www.capterra.com/learning-management-system-software/\#infographic

[15] Moodle - Open-source learning platform | Moodle.org. (2017). Moodle.org. Retrieved from the website: https://moodle.org/?lang=ar

[16] Blackboard | Education Technology \& Services. Blackboard.com. Retrieved from the website: http://www.blackboard.com/index.html

[17] Bri, D., Garcia, M., Coll, H., \& Lloret, J. (2007). A Study of Virtual Learning Environments.

[18] Kumar, S., Gankotiya, A. K., \& Dutta, K. (2011). A Comparative Study of MOODLE with other e-Learning Systems.

[19] Logan, K., \& Neumann, T. (2010). Comparison of Blackboard 9.1 and Moodle 2.0.

[20] Compare moodle vs blackboard 2017 | finances online. Financesonline.com. Retrieved from the website: https://comparisons.financesonline.com/moodle-vs-blackboard-learn

[21] Koster, R. (2005). A Theory of Fun for Game Design. Scottsdale. Arizona: Paraglyph Press.

[22] Salen, K., \& Zimmerman, E. (2003). Rules Play: Game Design Fundamentals. Cambridge, MA, USA: MIT Press.

[23] Ulicsak, M., \& Williamson, B. (2011). Computer Games and Learning: A Handbook. London: Futurelab.

[24] Connolly, T. M., Stansfield, M., \& McLellan, E. (2006). Using an online games-based learning approach to teach database design concepts. Electronic journal of e-Learning, 4(1), 103-110.

[25] Connolly, T. M., Stansfield, M., \& Hainey, T. (2007). Using games-based learning to teach software engineering. WEBIST, 304-31.

[26] Simões, J., Redondo, R., \& Vilas, A. (2012). A Social gamification framework for a K-6 learning platform. Computers in Human Behavior, 28.

[27] Cristina, I. M. Raising Engagement in e-Learning through Gamification.

[28] Ibanez, M., Di-Serio, A., \& Delgado-Kloos, C. (2014). Gamification for engaging computer science students in learning activities: A case study. IEEE Transactions on Learning Technologies, 7(3).

[29] Simões, J., Redondo, R., Vilas, A., Aguiar, A. (2013). A gamification framework to improve participation in social learning environments. E-Learning Papers.

[30] Malone, T. W. (1980). What makes things fun to learn? Heuristics for designing instructional computer games. Proceedings of the 3rd ACM SIGSMALL symposium and the first SIGPC symposium on Small systems - SIGSMALL '80 (pp. 162-169). USA: ACM Press, 1980.

[31] Bowman, R. F. (1982). A Pac-Man theory of motivation. Tactical implications for classroom instruction. Educational Technology, 22(9), 14-17.

[32] Deterding, S., Khaled, R., Nacke, L., Dixon, D. (2011). Gamification: Toward a definition. Proceedings of CHI 2011 Gamification Workshop, Canada.

[33] Shneiderman, B. (2004). Designing for fun: How can we design user interfaces to be more fun? Interactions, 11(5), 48-50.

[34] Werbach, K., \& Hunter, D. (2012). For the win: How game thinking can revolutionize your business. Philadelphia: Wharton Digital Press.

[35] Flatla, D., Gutwin, C., Nacke, L., Bateman, S., \& Mandryk, R. (2011). Calibration games: Making 
calibration tasks enjoyable by adding motivating game elements. California: UIST, Santa Barbara.

[36] Viola, F. (2011). Gamification I videogiochinella vita quotidiana. Arduino Viola.

[37] Khan Academy. (2017). Khan Academy. Retrieved from the website: https://www.khanacademy.org/

[38] Learn all about ClassDojo \. (2017). ClassDojo. Retrieved from the website: https://www.classdojo.com/

[39] Portelli, J. P., \& McMahon, B. (2004). Engagement for what? Beyond popular discourses of student engagement. Leadership Policy Schools, 3(1), 59-76.

[40] Schlechty, P. (1994). Increasing student engagement. Missouri Leadership. Acad.

[41] Siemens, G. (2004). Learning Management Systems: The Wrong Place to Start Learning, elearnspace. Retrieved from the website: http://www.elearnspace.org/Articles/lms.htm

[42] Ehlers, U. D. (2009). Web 2.0 - e-learning 2.0 - Quality 2.0? Quality for new learning cultures. Quality Assurance in Education, 17(3), 296-314.

[43] Urh, M., Vukovic, G., Jereb, E., \& Pintar, R. (2015). The model for introduction of gamification into e-learning in higher education. Proceedings of the 7th World Conference on Educational Sciences, (WCES-2015), Novotel Athens Convention Center, Athens, Greece.

[44] Monterra, B., Lavoué, É., \& George, S. (2011). Toward personalised gamification for learning environments. adfa, 1.

[45] Fogg, B. J. (2009). A behavior model for persuasive design. Proceedings of the 4th International Conference on Persuasive Technology.

[46] Raymer, R. (2011). Gamification: Using game mechanics to enhance elearning. eLearn, 2011(9), 3.

[47] Petrovic, V., \& Ivetic, D. (2012). Gamifying education: A proposed taxonomy of satisfaction metrics. Proceedings of the 8th Int. Sci. Conf. eLearn. Softw. Edu. (pp. 345-350).

[48] Nicholson, S. (2012). A user-centered theoretical framework for meaningful gamification. Proceedings of Games Learn. Soc. 8.0 (pp. 223-230).

[49] Barata, G., Gama, S., Jorge, J., \& Gonçalves, D. (2013). Engaging Engineering Students with Gamification-n Empirical Study.

[50] Jayasinghe, U., \& Dharmaratne, A. (2013). Game based learning vs. gamification from the higher education students' perspective. Proceedings of IEEE International Conference on Teaching, Assessment and Learning for Engineering (TALE) (p. 683).

[51] Berkling, K., \& Thomas, C. (2013). Gamification of a software engineering course- and a detailed analysis of the factors that lead to its failure. Proceedings of International Conference on Interactive Collaborative Learning (ICL) (p. 525).

[52] Domínguez, A., Saenz-de-Navarrete, J., de-Marcos, L., Fernández-Sanz, L., Pagés, C., \& Martínez-Herráiz, J. (2013). Gamifying learning experiences: Practical implications and outcomes. Computers \& Education, 63, 380-392.

[53] Todor, V., \& Pitică, D. (2013). The gamification of the study of electronics in dedicated e-learning platforms. Spring Seminar on Electronics Technology, 428.

[54] Akpolat, B., \& Slany, W. (2014). Enhancing software engineering student team engagement in a high-intensity extreme programming course using gamification. Proceedings of IEEE 27th Conference on Software Engineering Education and Training (CSEE\&T) (p. 149).

[55] Ibanez, M., Di-Serio, A., \& Delgado-Kloos, C. (2014). Gamification for engaging computer science students in learning activities: A case study. IEEE Transactions On Learning Technologies, 7(3), 291.

[56] Auvinen, T., Hakulinen, L., \& Malmi, L. (20150. Increasing students' awareness of their behavior in online learning environments with visualizations and achievement badges. IEEE Transactions on Learning Technologies, 8(3), 261-273. 
[57] de-Marcos, L., Garcia-Lopez, E., \& Garcia-Cabot, A. (2016). On the effectiveness of game-like and social approaches in learning: Comparing educational gaming, gamification \& social networking. Computers \&Education, 95, 99-113.

[58] Hew, K. F., Huang, B., Chu, K. W. S., \& Chiu, D. K. (2016). Engaging Asian students through game mechanics: Findings from two experiment studies. Computers \& Education, 92, 221-236.

[59] Ortiz-Rojas1, M., Chiluiza, K., \& Valcke, M. (2017). Gamification in computer programming: Effects on learning, engagement, self-efficacy and intrinsic motivation. Proceedings of European Conference on Game Based Learning.

[60] Zamora, F., Carlosa, J., Aranda, \& Daniel, A. (2017). Implementation of a gamification platform in a master degree (Master in Economics). Working Papers on Operations Management, 8, 81-190.

[61] Wang, X., Fan, J., \& Sun, G. (2012). The exploration and practice of data structure teaching based on CDIO model. Proceedings of the 7th International Conference on Computer Science \& Education.

[62] Garcia, R. A., \& Al-Safadi, L. A. (2014). Intervention strategies for the improvement of students'academic performance in data structure course. International Journal of Information and Education Technology, 4(5).

[63] Byrne, M. D., Catrambone, R., \& Statsko, J. T. (1996). Do algorithm animations aid learning? Tech. Rep. GIT-GVU-96-18.

[64] Hundhausen, C., Douglas, S., \& Stasko, J. (2002). A meta-study of algorithm visualization effectiveness. Visual Languages and Computing, 13(3), 259-290.

[65] Naps, T. L., Rößling, G., Dann, W., Almstrum, V., Fleischer, R., Hundhausen, C., \& Korhonen, A. (2002). Exploring the role of visualization and engagement in computer science education. ACM SIGCSE Bulletin, 5(2), 131-152.

[66] Patel, S. (2014). A literature review on tools for learning data structures. University of Cape Town.

[67] Shabanah, S., \& Chen, J. X. (2009). Simplifying algorithm learning using serious games. Proceedings of the 14th Western Canadian Conference on Computing Education.

[68] Lawrence, R. (2003). Teaching data structures using competitive games. IEEE Transactions on Education

[69] Deterding, S. (2012). Gamification: Designing for motivation. Interactions, 19(4), 14-17.

[70] Deci, E., \& Ryan, R. (2004). Handbook of Self-Determination Research. University of Rochester Press.

[71] Ryan, R. M., \& Deci, E. L. (2000). Self-determination theory and the facilitation of intrinsic motivation, social development, and well-being. American Psychological Association, 55(1), 68-78.

[72] Przybylski, A. K., Rigby, C. S., \& Ryan, R. M. (2010). A motivational model of video game engagement. Review of General Psychology, 14(2), 154-166.

[73] Marache-Francisco, C., \& Brangier, E. (2013). Perception of gamification: Between graphical design and persuasive design. Marcus A. (eds) Design, User Experience, and Usability. Health, Learning, Playing, Cultural, and Cross-Cultural User Experience.

Reem S. Al-Towirgi is a teaching assistant in the Faculty of Computing and Information Technology at Taif University, Taif, Saudi Arabia. Currently, she is a master student, Faculty of Computing and Information Technology, King Abdulaziz University, Jeddah, Saudi Arabia. She obtained a B.Sc from the Computer Science Department, Faculty of Science, King Abdulaziz University in 2007. Her research interest includes e-leaning, gamification, and data mining.

Lamya Fouad Daghestani is an assistant professor in the Faculty of Computing and Information Technology at King Abdulaziz University. She obtained the bachelor degree from Computer Science, Faculty 
of Sience, King Abdulaziz University 1989. She obtained a master's degree from Department of Informatics / Digital Media, Computing and Engineering, University of Huddersfield 2007. She obtained a doctorate degree from Digital Media, Computing and Engineering, University of Huddersfield, 2013. Her research interests include computer graphics, virtual reality and virtual environments, e-learning technologies, e-library management, search engines and the semantic web.

Lamiaa Fattouh Ibrahim is a professor in the Faculty of Computing and Information Technology at King Abdulaziz University in Jeddah and in the Institute of Statistical Studies and Research at Cairo University. She obtained a Ph.D from the Faculty of Engineering, Cairo University in 1999, a master's degree from the Computer and Systems Engineering Department in the Faculty of Engineering, Ain Shams University in 1993, a master's degree from the Ecole National Superieur de Telecommunication, ENST Paris in 1- 987, and a B.Sc from the Computer and Automatic Control Department, Faculty of Engineering, Ain Shams University in 1984. She has over 33 years of experience in the fields of network engineering and artificial intelligence, focusing on applying knowledge base and data mining techniques in wired and wireless network planning. She has published papers in many international journals and international conferences in the areas of networks, data mining, and wired and mobile network planning. 